\title{
Strengthening the Position of Expert Witness in Judicial Process
}

\author{
Indriati Amarini' ${ }^{1}$, Ratna Kartikawati ${ }^{2}$ \\ ${ }^{1}$ Faculty of Law, Universitas Muhammadiyah Purwokerto, Indonesia. E-mail : indriatiamarini@ump.ac.id \\ ${ }^{2}$ Faculty of Law, Universitas Muhammadiyah Purwokerto, Indonesia. E-mail : ratnakartikawati@ump.ac.id
}

\begin{tabular}{l} 
ARTICLE INFO \\
\hline Keywords: \\
expert witness; expert \\
testimony; judicial process \\
How to cite: \\
Amarini, I E Kartikawati, \\
R. (2020). Strengthening \\
the Position of Expert \\
Witness in Judicial \\
Process. JURNAL \\
MEDIA HUKUM, $27(1)$, \\
44-54. \\
Article History: \\
Received: $17-10-2019$ \\
Reviewed: 20-06-2020 \\
Revised: 23-06-2020 \\
Accepted: 26-06-2020
\end{tabular}

\begin{abstract}
An expert witness is a person requested to give testimony based on his/her specific expertise in a court trial. Expert testimony is needed to help the judges discovering the truth. A problem emerges when the expert witness is sued for his/her testimony by the losing party. The purpose of this research is to elaborate the role of expert witness and the need to strengthen its position in judicial process. This doctrinal research relies on the secondary data and employs a qualitative juridical analysis. The result of the research shows that the expert testimony is needed to clarify particular issue that cannot be addressed by the judges themselves. Considering its importance, the expert witnesses should be able to give their testimonies freely and protected from any legal action due to their testimonies.
\end{abstract}

DOI: 10.18196/jmh.20200141

Copyright @ 2020 MEDIA HUKUM. All rights reserved.

\section{Introduction}

An expert witness is a person requested to give information because of his/her expertise, not his/her involvement in a case being heard. In other words, the expert witness gives testimonies not about what he/she have seen, heard, or experienced, but about the things becoming his/her expertise, which relate to the case being examined by the judge. The expert testimony is needed in a court process requiring information or explanation, which cannot be addressed by the judge him/herself.

The expert witness is often presented in every court process in Indonesia. ${ }^{1}$ Ideally, an expert called for giving testimony before the court trial has sufficient professional qualification. Furthermore, the testimony should be given based on his/her expertise. However, expert witnesses who give testimonies not in accordance with their expertise are still found in practice. For instance, in the case of large forest and land fires in 2015, a forestry expert from Bogor Agricultural Institute, Hero Saharjo, asked the Minister of

\footnotetext{
1 Amarini, I. (2019). Saksi Ahli Dalam Praktik Peradilan. Saraswati Nitisara, p. 1.
} 
Research and Higher Education to reprimand any rector giving permission to any lecturer for becoming an expert witness for a case which was not in accordance with his/her expertise. ${ }^{2}$

Recent development shows that an expert witness may be exposed to an unhappy experience of being sued due to his/her expert testimony. This happens especially when his/her testimony has caused losses on particular parties. Such an unhappy experience has ever been encountered by Basuki Wasis.

On April 17, 2018, Cibinong District Court, West Java, held a hearing for a civil case between Nur Alam (the plaintiff) ${ }^{3}$ versus Basuki Wasis (the defendant). The defendant was the environmental expert witness who calculated the environmental losses on a corruption case of PT Anugerah Harisma Barakah (AHB). ${ }^{4}$

The plaintiff himself has also been convicted in the mentioned corruption case. He was proven guilty for enriching the $\mathrm{AHB}$ around 1.5 trillion rupiahs by granting the mining license. Consequently, the court imposed 12 years of imprisonment and 1 billion rupiahs of fine on March 28, 2018.

As an expert witness in the mentioned case, ${ }^{5}$ the defendant had calculated that loss suffered by the state in the given case was 2.728 billion rupiah from the environmental degradation in Kabaena Island due to nickel mining, with the total area of 357.2 hectare. The calculation is based on the Minister of Environment Regulation No. 13 of 2011 on Compensation for Losses due to Pollution and/or Environmental Damages and the Minister of Environment Regulation No. 7 of 2014 on Environmental Losses due to Pollution and, or Environmental Damages.

The defendant's testimony has been used by the plaintiff as the basis for filing a civil suit against the defendant in Cibinong District Court in early 2018. The civil suit referred Article 1365 of the Civil Code which states that every unlawful act that causes damage to other person, obliges the person at fault to compensate that loss. ${ }^{6}$ The Defendant was sued to pay financial compensation as much as 1.7 billion rupiahs for material losses, and 3 trillion rupiahs for immaterial losses.

Pros and cons appeared especially among civil society organizations which assume that the government must be serious in protecting anyone who struggles for the environment, including expert witnesses, indigenous people, and environmental advocates. If the above lawsuit is accepted, it will be a terror for anyone becoming an expert witness in a trial, one of which is the academics defending the environment and state interest.

This article discusses the reposition of an expert witness presented in a court process. Further, it answers the question on how to strengthen the position of expert witness in court trial to help the judge realizing the justice.

\footnotetext{
2 Forestry Expert of IPB asked the Minister of Research, Technology, and Higher Education to Reprimand Rectors Related to Expert Witnesses.http:/ /www.Warta Ekonomi.co.id [Accessed August 14, 2016]

3 The plaintiff was the non-active Governor of South East Sulawesi.

${ }^{4}$ AHB is a limited liability company holding a Nickel Mining License.

5 The defendant was called for by the prosecutor from the Corruption Eradication Commission.

6 Rachman, D. A. (2018). An expert witness from IPB (Bogor Agricultural Institute) in Nur Alam's trial, KPK-LPSK (Corruption Eradication Commision- Victim and Witness Protection Agency) gave legal assistance. Available online from : https://nasional.kompas.com [Accessed May, 2018].
} 


\section{Method}

The type of the research is doctrinal or normative legal research. The research employs secondary data in the form of primary, secondary and tertiary legal materials which were collected through library-based study. The analysis of legal materials uses qualitative juridical analysis.

\section{Result and Analysis}

\subsection{Definition of Expert Witness}

An expert witness according to the Indonesia Dictionary is a person becoming a witness because of his/her expertise. In giving the testimony, an expert only conveys what becomes his/her expertise, which relates to the case being heard. Experts or professional experts presented in a court process are those having education, training, skills, or experience which are believed to have specific skills and knowledge in a certain field.

The definition of expert testimonies can be seen in the Criminal Procedure Code. Article 186 of the Criminal Procedure Code states that expert testimonies are the testimonies given in a trial. The expert testimonies can also be given during the examination by the investigators or public prosecutors outlined in a form of a report, made by remembering the oath taken when receiving a position or a job. If the testimonies are not given at the examination by the investigators or the public prosecutors, they will be asked at the examination in the hearing and be recorded in the police investigation report. The testimonies are given after taking a promise or an oath in front of the judge.

Based on the above provision, the expert testimonies can be given at the level of written investigation or prosecution based on the oath. In the court trial, the expert is obliged to take an oath or promise as determined in Article 179 Paragraph (2) of the Criminal Procedure Code. This article lays down the obligation for the expert to provide best and most accurate testimonies based on his/her expertise.

Article 183 of the Criminal Procedure Code provides that the penalty can only imposed be judge based on at least two valid evidences. Further, it is determined that these evidences help the penal of judges to believe that the accused is guilty. For this purpose, there should be an examination on the evidences presented before the court. According to Article 184 of the Criminal Procedure Code, the valid evidences include: (1) keterangan saksi (witness testimony); (2) keterangan ahli (expert testimony); (3) alat bukti surat (documentary evidence); (4) alat bukti petunjuk (circumstantial evidence); and (5) keterangan terdakwa (the accused's statement).

In this paper, special concern will be given to the expert witness. As comparison, Federal Rules of Evidence of the United States also uses the term professional witness or judicial expert. Under this Rules, an expert witness is defined as a witness, who by virtue of education, training, skill or experience, is believed to have expertise and specialised knowledge in a particular subject beyond that of the average person, sufficient that others may officially and legally rely upon the witness's specialised (scientific, technical or other) opinion about an evidence or fact issue within the scope of his expertise, referred to as the expert opinion, as an assistance to the fact finder . 


\subsection{Duties and Functions of Expert Witness}

Expert's duties and functions in a court process are determined in the Criminal Procedure Code:

Table 1: Expert Witness in the Criminal Procedure Code

\begin{tabular}{|c|c|c|}
\hline No & $\begin{array}{l}\text { Articles of the } \\
\text { Criminal } \\
\text { Procedure Code }\end{array}$ & Article's Content \\
\hline 1 & $\begin{array}{l}\text { Article } 132 \\
\text { Paragraph (1) }\end{array}$ & $\begin{array}{l}\text { In terms of a complaint received that a letter or a writing is false or falsified or } \\
\text { suspected to be false by the investigators, for the purpose of investigation, a } \\
\text { testimony on those terms is requested from an expert }\end{array}$ \\
\hline 2 & $\begin{array}{l}\text { Article } 133 \\
\text { Paragraph (1) }\end{array}$ & $\begin{array}{l}\text { In terms of the investigator, for the purpose of the trial, deals with a victim, } \\
\text { whether injured, poisoned or dead due to a criminal act, he/she is authorized } \\
\text { to submit a request for an expert testimony to the judicial medical expert or } \\
\text { doctors or other experts. }\end{array}$ \\
\hline 3 & $\begin{array}{l}\text { Article } 179 \\
\text { Paragraph (1) }\end{array}$ & $\begin{array}{l}\text { Anyone being asked for his/her opinion as a judicial medical expert or a } \\
\text { doctor or other experts is obliged to give expert testimonies for justice. }\end{array}$ \\
\hline 4 & $\begin{array}{l}\text { Article } 179 \\
\text { Paragraph (2) }\end{array}$ & $\begin{array}{l}\text { Will provide the best and the most accurate testimonies according to the } \\
\text { knowledge of his/her expertise. }\end{array}$ \\
\hline 5 & Article 183 & $\begin{array}{l}\text { The judge imposes the criminal verdict based on at least two valid evidences } \\
\text { which can shape the judges' conviction about the accused's guilt. The } \\
\text { formation of the judge's conviction in imposing the criminal verdict is based } \\
\text { on the result of examining the evidences found in the court process. }\end{array}$ \\
\hline 6 & Article 184 & $\begin{array}{l}\text { The valid evidences include testimonies of the witnesses and the experts, } \\
\text { letters, instructions, and the accused's statement. }\end{array}$ \\
\hline 7 & Article 186 & $\begin{array}{l}\text { The expert testimonies can be given at the level of written investigation or } \\
\text { prosecution based on the oath of office. }\end{array}$ \\
\hline
\end{tabular}

Based on the above articles, the existence of the expert aims to increase the judge's conviction in imposing a verdict. As stated by Dame Elizabeth Butler-Sloss, a prominent former judge in the UK, that "expert witnesses are a crucial role, without them we (the judges) cannot do our job."

Criteria or requirements of an expert presented in a court process are not in detail regulated in the Criminal Procedure Code. Anyone can be an expert if he/she has a specific expertise which can be obtained through formal and non-formal education. In practice, the educational background and certification as well as experiences owned by a person become the consideration for the judge.

The requirements for an expert include academic qualification and practicing experience. The academic qualification relates to the educational background of the expert, either formal or informal education. Meanwhile, the practicing experience refers to experience of the expert in implementing knowledge in his/her professional work. This requirement commonly relates to the quality (how successful an expert provides evidences which help the judge in making decision), the case quantity (how many cases handled), and the time (how long a person has become an expert).

As a comparison, the criteria of an expert are determined by various things, as contained in California Evidence Code on Qualification as an expert witness, crossexamination of expert witness, credibility of expert witness, limit on number of expert 
witness. Meanwhile, an expert qualification is: a person is qualified to testify if he has special knowledge, skill, experience, training or education sufficient to qualify him as an expert on the subject to which his testimony relates. Against the objection of a party, such special knowledge, skill experience, training, or education must be shown before the witness may testify as an expert.

Figure 1:

Qualification of Expert Witness According to Debra Sinder

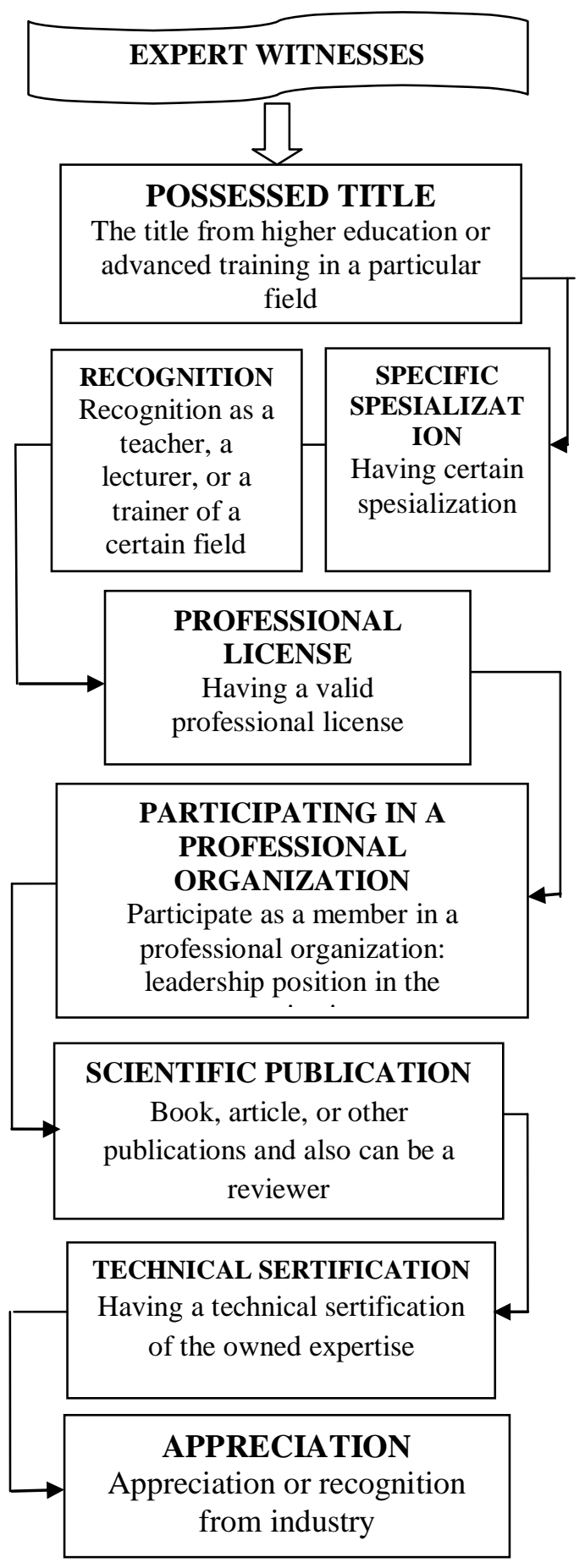


Debra Shinder suggests several factors and criteria an expert witness must have that include: (1) having higher education degree or advanced training on particular field, (2) having specific specialization, (3) being recognized as a teacher, a lecturer, or a trainer in a particular field, (4) having a professional license, if still valid, (5) participating as a member of a professional organization, (6) having a book, article or other publications, and also can be a reviewer. This will be one of the supporters that the expert witness has a long-term experience, (7) having a technical certification, (8) receiving an award and recognition from industry (see Figure 1)

An expert must have the following qualities: (1) knowledge and practical experience of the materials discussed in the case, (2) the ability to communicate about a finding or opinion which will be clearly and concisely delivered and can be understood by the lay parties involved in the trial, (3) flexible in terms of mind and self-confidence to modify opinions as a new evidence or an opposite argument, (4) the ability to think from the different side in order to be able to master any situation possibly occur in the trial, (5) convincing attitude and appearance in the trial.

Based on the research conducted by Andrew W. Jurs, there are several factors that influence the judges in evaluating an expert in a court. Those factors are sequentially as follows: (1) Ability to convey technical information in a nontechnical fashion; (2) Impressive educational credentials; (3) Willingness to draw firm conclusions; (4) Pleasant personality; (5) Leading expert in field; and (6) Attractive physical appearance (see Figure 2).

\section{Figure 2: Effectiveness of Expert Witness}

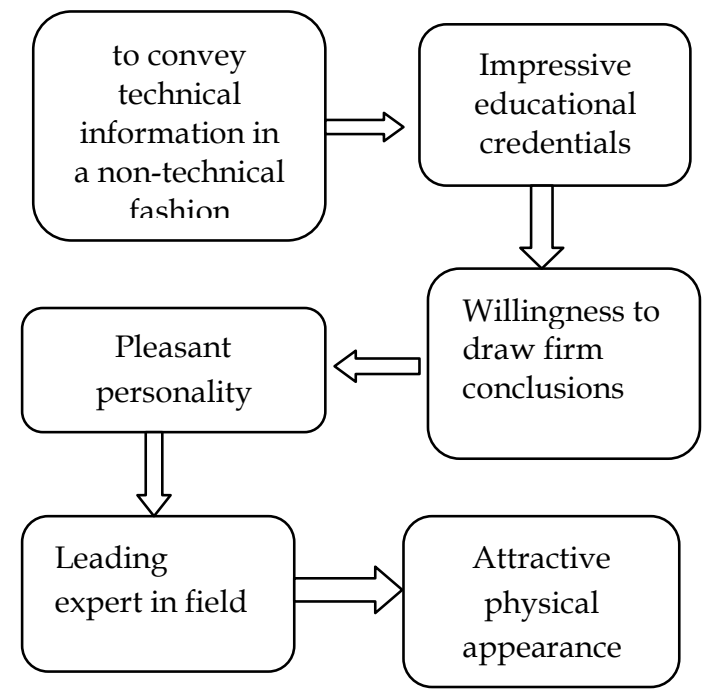

There are differences of the experts presented in a court process of Indonesia with those presented in Europe or the Unites States. The expert heard at the hearing is the expert who is asked for testimonies related to his/her specific knowledge other than law. However, nowadays there is an arising symptom that the presented expert witness frequently comes from the legal expert. ${ }^{7}$

7 Bedner, A. W. (2010). In Krishnamurti, I. (trans). Administrative Court in Indonesia: A Social-legal Study. Van Volehoven Institute, p. 323. 
This phenomenon gives the impression of declining scientific (legal) quality among the law enforcement officers. This is because the matters being asked are about the legal problems or theories, which should have been known by them (they are indeed a legal expert too). This symptom indicates the pragmatic/shortcut culture or approach in understanding the law or the science of law, that is want to quickly get the core or the extract from the witness or the expert without bothering themselves to independently dig in and explore it. ${ }^{8}$

Related to the existence of experts, Adrian W. Bedner states that the matter is actually based on the lack of trust of the defendant's lawyer and attorneys, which then encourages the emergence of accusatory aspects in the state administrative court procedures and is mainly about the opportunity to appoint a legal expert. Almost all experts presented, especially at the State Administrative Court, are a legal expert. The experts' role is to assert the authority of the verdict. Sometimes, those legal experts provide different views so that the judge only has to choose which one finally be used in his/her verdict. ${ }^{9}$

A judge acts as a gate keeper to assess whether the expert has the competence to help the judge in finding the substantive truth so that a fair decision can be enforced. This is because principally the presence of a third party (the expert) into a criminal trial process is a restricted matter. For example, in a corruption case involving the former Head of the Regional Office of the East Kalimantan Department of Forestry and Plantation, Uuh Ali Yudin. The Panel of Judges chaired by Kresna Menon rejected the expert proposed by the accused even though that expert had a doctoral degree in criminal law. The reason for this rejection was based on the fact that there was no criminal law material which should be explained in that case because the Panel of Judges themselves were also considered as criminal law experts.

The judge's tendency to use a partial, pragmatic, and shortcut thinking related to an expert or expert witness in a judicial practice of litigation in the United States is said to be only a theatrical attempt to influence the judges. With regard to this, Richard A. Posner states as follows: "A further problem with expert witnesses is that for many of them, litigation is their ordinary even their only work. Their technical skills may be minimal, their real skill being theatrical-the ability a charm or dazzle a jury". ${ }^{10}$

\subsection{Ethics and Professionalism of Expert Witness}

Ethics are moral values and norms becoming a guideline for a person or group in regulating their behaviour. In addition, ethics are also defined as a knowledge about what is good and bad and about moral rights and obligation. Ethics and professionalism are the "spirit" of a job which are wrapped up by the soul called an expert.

The ethics of being an expert presented in a court process are not specifically regulated. Professional ethics are regulated in the code of ethics of each profession. However, in Article 22 of the Constitutional Court Regulation No. 06/PMK/2005 on the Judicial Review Guidelines, there are provisions regarding the expert presented in a trial, such as: (1) the expert can be proposed by the petitioner, president/government, House of

\footnotetext{
8 Syamsudin, M. (2011). Rekonstruksi Perilaku Etik Hakim Dalam Menangani Perkara Berbasis Hukum Progresif. Jurnal Hukum, 18(Edisi Khusus), p. 129.

9 Bedner, A.W., op. cit., p. 323.

10 Posner, R. A. (2013). Reflections on Judging. Harvard University Press, p. 44.
} 
Representatives, Regional Representative Council, related parties, or summoned by order of the Court; (2) the expert testimony which can be considered by the Court is the testimony delivered by a person having no individual interest; and (3) examination of an expert begins by asking the identity (name, place and date of birth, religion, job, and address) and curriculum vitae as well as the expertise. The expert is also asked about his/her willingness to take an oath or promise according to his/her religion to give testimonies in accordance to his/her expertise.

As comparison, the guidelines for becoming an expert presented in a court process are regulated in detail. These can be seen in the Guidelines for the Expert Witness as follows: (1) only attending a court issuing a written summons ordering to appear in a hearing; (2) bringing a complete file or document needed in a court by following the given instruction; (3) clarifying what the expected expertise is at the trial; (4) asking and clarifying the needed written report by the trial; (5) reviewing the file and information relevant with the case in order to refresh the memory, focus on important facts and issues to increase the credibility of testimonies; (6) ensuring the time to attend the trial; (7) asking, if needed, about when a meeting before the hearing can be conducted to find out under what case the testimonies are needed and who makes the decision; and (8) asking whether there are other expert witnesses and when they are appointed to attend;11 (9) preparing curriculum vitae and other documents related to relevant education, training, experience, and knowledge in order to prove the credibility of the expert witness's testimony; and (10) since an expert witness acts under a code of ethics and confidentiality, it needs a clear understanding of the court protection to the expert witness and how the protection is provided to avoid violation of the code of ethics which may arises while giving testimony.

Furthermore, Robert Ambrogi proposed code of ethics for expert witnesses which can be applied together. The code of ethics includes: (1) a neutral attitude of expert witnesses; (2) confidentiality; (3) cost; (4) ex parte relation or unjustified communication with one of the parties or with the law; (5) conflict of interest; and (6) professionalism.

Besides preparing the code of ethics, the supervision upon the implementation of the ethics is also necessary. This is in order not to be fall into the phenomenon of "the given talks depend on the one who pays". It is necessary to avoid the battle of expert that is a situation when a lawyer and a prosecutor present their chosen experts who deliver their own may even be very extreme-theories and end up in a conclusion which is in accordance with the position of the inviting party.

\subsection{Expert Witness Protection}

Expert testimonies are needed in every litigation process that requires testimonies or explanation about a case, which cannot be addressed by the judge him/herself. This is because principally the testimonies will clarify the case for the purpose of better examination process.

\footnotetext{
11 This is to anticipate conflict of opinion if a different understanding emerged among the witnesses. As the expert witness asked to give testimonies, he/she may submit the time of attending the trial which differs from the time of other expert witnesses
} 
The use of expert testimony as an evidence cannot be separated from the theory of punishment in criminal law. David Garland states that classical notions of justice and responsibility began to be replaced by modern, scientifically ordered alternatives. ${ }^{12}$

The adoption of expert testimonies as evidence within the Indonesian Criminal Procedure Code is a good progress. Moreover, the development of knowledge and technology has also increased the quality of crime methods which require the role of expert for better verification of cases.

The emergence of expert testimony as evidence is an effort rectify the practice of kampetai which often uses violence and torture to obtain confession from the suspects and/or the accused. The presence of expert testimonies will help the law enforcement agencies to rely more on scientific crime detection. ${ }^{13}$

The change of evidence introduced during process of criminal law reform indicates that there is an effort to make the criminal law suitable with the future need. Expert testimonies is one of the tools to prevent error of judgment during the examination process. From the perspective of due process model, the use of expert testimony aims to establish definitive factual guilt. Consequently, informal fact finding using torture, spies or informants and false witnesses is prohibited. As such, the mission to discover the substantive truth through criminal proceedings is much more possible.

With regard to the above matter, the presence of expert witnesses crucial because they may help the judge to understand a confusing matter that lead to doubt. Thus, expert testimonies also play an important role in providing a minimum evidence which can be used to prove the accused's guilt. ${ }^{14}$

As a matter of fact, there are two environmental experts who have been sued in civil court due to their testimonies as expert witnesses. Their testimonies were given in two different criminal cases, but both relate to environmental crimes. Such a civil suit threatens academic freedom and endangers law enforcement processes.

Bambang Heru Sahardjo, an academic from Institut Pertanian Bogor (IPB) argues that lawsuit can deter experts to give testimonies in court trial. What has been encountered by Basuki Wasis (as explained in the introduction) becomes an alert for other experts. They will think that they may face similar problem when they stand as expert witness in court trial. Therefore, a protection of expert witnesses is necessary considering their crucial roles.

\section{Conclusion}

An expert witness is a person becoming a witness because of his/her expertise. An expert delivers what becomes his/her specific expertise related to the case being heard. The expert testimonies are needed in a trial requiring testimonies or explanations from an expert to clarify a case for the purpose of examinations. In criminal case, expert testimony is important for helping the panel of judges discovering the substantive

12 Respati, L. (2012). Keberadaan Ahli dan Implikasi Negatifnya Terhadap Asas Peradilan Cepat, Sederhana dan Biaya Ringan (Suatu Kritik Terhadap Pemeriksaan Ahli dalam Peradilan Pidana di Indonesia). Jurnal Negara Hukum, 3(2), p. 250.

${ }^{13}$ Ibid., p. 260

${ }^{14}$ Harahap, Y, (2000). Pembahasan Permasalahan Dan Penerapan KUHAP, Pemeriksaan Sidang Pengadilan, Banding, Kasasi dan Peninjauan Kembali. Sinar Grafika, p. 283. 
truth. Therefore, the protection of expert witness is necessary and the position of expert witness should be strengthened within judicial system. This can be achieved among others by establishing a code of ethics for expert witness and supervising its implementation.

\section{Acknowledgments}

This article was the result of Professorship Acceleration Grants Research of Universitas Muhammadiyah Purwokerto Number: A.11-III/697-S.Pj./LPPM/XI/2016.

\section{References}

Books:

Amarini, I (2019). Saksi Ahli Dalam Praktik Peradilan. Saraswati Nitisara.

Bedner, A. W. (2010). In Krishnamurti, I. (trans). Administrative Court in Indonesia: A Social-legal Study. Van Volehoven Institute.

Harahap, Y, (2000), Pembahasan Permasalahan Dan Penerapan KUHAP, Pemeriksaan Sidang Pengadilan, Banding, Kasasi dan Peninjauan Kembali. Sinar Grafika.

Posner, R. A. (2013). Reflections on Judging. Harvard University Press.

\section{Journal Articles:}

Jurs A. W. (2016). Expert Prevalence, Persuasion and Price: What Trial Participant Really Think About Expert. Indiana Law Journal, 91(2), 353-391.

Meliala, A. (2008). Kontribusi Psikologi dalam Dunia Peradilan: Dimana dan Mau Kemana. Indonesian Journal of Legal and Forensic Sciences, 1(1), 56-59.

Respati, L. (2012). Keberadaan Ahli dan Implikasi Negatifnya Terhadap Asas Peradilan Cepat, Sederhana dan Biaya Ringan (Suatu Kritik Terhadap Pemeriksaan Ahli dalam Peradilan Pidana di Indonesia). Jurnal Negara Hukum, 3(2), 249-273.

Rika, S. (2013). Peran Dokter Sebagai Saksi Ahli di Persidangan. Jurnal Kesehatan Andalas,2(2), 101-104.

Syamsudin, M. (2011). Rekonstruksi Perilaku Etik Hakim Dalam Menangani Perkara Berbasis Hukum Progresif. Jurnal Hukum, 18(Edisi Khusus), 127-145.

\section{Internet:}

Ahli Kehutanan IPB Minta Menristekdikti Tegur Rektor Terkait Saksi Ahli. Http:/ / www.Warta Ekonomi.co.id [Accessed August 14, 2016]

California Evidence Code. http://www.law.harvard.edu [Accessed December 22, 2016]

Ambrogi, R. (2009). Proposed: Expert witnesses Code of ethics. IMS ExpertServices. Available online from: https://www.ims-expert services.com. [Accessed December 25, 2016] 
Rachman, D. A. (2018). Saksi Ahli dari IPB di siding Nur Alam Digugat, KPK-LPSK Beri Pendampingan Hukum. Available online from : https://nasional.kompas.com. [Accessed May, 2018].

Tim Penyusun Kamus Pusat Bahasa. (2008). Kamus Bahasa Indonesia, Pusat Bahasa. 